\title{
FACTORS INFLUENCING THE ADOPTION OF MICROENTERPRISES AND THEIR IMPACT IN RURAL GUATEMALA
}

\author{
Nicolas Gennrich, Ph.D. \\ EXPERTO INTERNACIONAL EN DESARROLLO RURAL \\ nicolasgennrich@hotmail.com
}

\begin{abstract}
Resumen
Cada vez hay mayor consenso respecto a que el ingreso no agropecuario representa una fuente importante para el sostenimiento del hogar en zonas rurales, pues los recursos provenientes de la producción agrícola son insuficientes. Cabe preguntarse en qué medida las microempresas $(\mathrm{ME})$ ayudan a combatir la pobreza y qué factores motivan a los hogares a formar una ME. La presente investigación se realizó en El Quiché, Guatemala, provincia muy afectada por la pobreza extrema, la desnutrición y la desintegración, a causa de la guerra civil que duró 36 años. Se encuentra que la ME es el factor más significativo en los ingresos del hogar, pero, a diferencia de lo esperado, su efecto sobre la vivienda y nutrición es limitado. En cuanto a los factores significativos en la decisión de formar una ME, destacan: capital humano, capital social, tipos de cultivo y acceso al mercado. El trabajo explora también el efecto de las actividades colectivas, como la comercialización, en el desarrollo de la ME, ya que la implementación de ferias y tiendas comunales contribuye considerablemente a la reducción de los costos de transacción y a la ampliación del mercado.
\end{abstract}

\section{Theoretical background}

\subsection{Problem statement}

In the seventies and eighties rural entrepreneurial activities have been understated in comparison with agricultural and industrial labor. Even among agriculturists and those interested in rural development there has been the tendency to ne- glect the non-farm sector. Nevertheless, there is mounting evidence that off-farm income is an important source of farm and other rural households, including the landless poor (FAO, 1998: 305). Due to this situation, nowadays off-farm income in poor regions does have an increasing significance in the framework of agriculture and in the theoretical debate. The returns achieved out of agricultural production are 
often not high enough to guarantee sustainable livelihoods for the households. In order to secure their basic needs additional income sources are required. Advocators of the non-farm sector stress its role for successful income growth. They argue that rapid population growth and the limited absorptive capacity of the cities imply the need for livelihood diversification (De Janvry, 1994: 1183).

Non-farm activities encompass both income derived from wage earning paying activities and self-employment in commerce, manufacturing and other services (FAO, 1998: 283). This study focuses on off-farm microenterprises (MEs). MEs are defined as firms that comprise 1 to 10 persons (USAID, 1997: 1). In this study MEs refer to all self-employed nonfarm enterprises which are not directly involved in crop and animal activities. Due to the fact that in the study area the majority of MEs are not formally established, also informal entrepreneurial activities are considered as MEs. MEs do not include other income sources such as wage labor and remittances.

Due to the fact that MEs may be a suitable additional source of income generation, it would be of particular interest if such economic activities could also imply a reduction in rural poverty. The issue of poverty relief shall be essentially addressed in terms of the objective to rise the income level of rural MEs resulting in an improvement of the standards of living of the households. The issue of social capital has become of particular interest in the theoretical and empirical research. The current discussion in the literature suggests that social capital in terms of membership in social groups and relationships to other people favors the household welfare (Grootaert, 1998: 22) and entrepreneurial activities ${ }^{1}$. These are aspects which are explored in this study.

To fulfil the objective of poverty alleviation it is necessary to achieve an increase in the income of the grassroots. In some countries such as Brazil, the incidence of poverty in rural areas is more than twice that of urban centers (World Bank, 1996: 1) This raises the question to what extent off-farm MEs are a source of diversifying the rural income. FAO mentions two main factors which influence the decision made by rural households to set up a business: the incentive offered through an increase in the relative productivity compared to agricultural activities and the household's capacity in terms of education, income, and access to credits (FAO, 1998: 285). While better returns through ME-activities is a «pull» factor, inadequate farm output, incomplete crop insurances and risks of farming are «push» factors to undertake off-farm activities which may be the adoption of MEs. (FAO, 1998: 285). It is of interest to explore further the impact of the determinants on ME-adoption.

\subsection{Background to the selected project}

The case study deals with a project promoting non-farm activities in Guatemala. For several decades, the country has been facing extreme poverty, malnutrition, and disruption of civil organizations due to the 36 years lasting civil war. In spite of the official ending of the war in 1996, the adverse economic and social impacts are still prevailing. The population of the province

1, This argument is stated by several authors (Fafchamps, Barr among others). 
El Quiché is most severely affected by the economic effects of the civil war. $77,7 \%$ of the population in El Quiché is still living in poverty which is considerably above the average of the country: $69,9 \%$ (Peter, 1998: 1). Furthermore, this province with its capital Santa Cruz de Quiché is charactarized by an extraordinary high share of Indian population $(90 \%$ in rural areas) belonging to ethnic Maya-groups.

Taking into account the precarious situation in El Quiché, in 1996 the Guatemalan government implemented the project «Programa de Desarrollo Rural Regional en El Quiché, PRODEQ» (Program for Rural Regional Development in El Quiché) with support of the Deutsche Gesellschaft für Technische Zusammenarbeit, GTZ (German Agency for Technical Cooperation). The consultancy firm GFATerra Systems is subcontracted to execute the project.

The project has been offering ME-support since 1999. Project work is based on the rationale to provide integral support in several areas of rural development such as nutrition, reforestation, health, gender, and the promotion of ME-activities simultaneously. The main objective of the project is an improvement in the social and economic frame conditions of the rural population. The strategy to accomplish this aim is to build capacities among rural associations formed by microentrepreneurs for administration and management, and to stabilise their legal status. The promoting activities of the project targeting MEs embrace business training and technical assistance in diverse professions (weaving, embroidery, ceramics, grocery among others), the provision of collective micro-credits «Bancos Comunales», and the provision of support in collective action to enhance the commercialisation process.

\subsection{Research questions of the study}

In order to address the determinants which influence ME-adoption, the strategies of ME-promotion, and the outcome of ME-activities and project activities in poverty reduction, the principal objectives of this study are summarized in the following research questions:

Question 1: What are the demographic and socio-economic characteristics of the households who adopt MEs compared to those who do not?

Question 2: What characteristics at household and village level determine the starting of MEs? What constraints do exist for the adoption and performance of MEs?

Question 3: Which strategies of ME-promotion are applied to enhance the entrepreneurial performance?

Question 4: What are the outcomes of MEs with respect to poverty reduction in terms of the household income and the standard of living?

\subsection{Objective, conceptual frame- work and hypotheses of the study}

The main objective of this study is to identify factors which influence the adoption and performance of MEs to supplement farm income; and to assess the role of a rural development project in promoting the success of entrepreneurial activities in order to 
reduce poverty of rural households. Of particular interest is the role of social capital in the outcome of ME-activities.

The aim of the conceptual framework is to depict the study in a broader context of the issues related to the adoption and promotion of MEs. The interactive factors are visualised in a chart where the adoption of MEs is conceived as the centre of a system determined by numerous interacting factors.

Figure 1 presents the conceptual framework of the entire study. The left square boxes refer to the determinant factors which are conceptualised at two levels, the village and the household level. The effect of the factors on adoption can either be direct or indirect through project support as illustrated by the circular box. The existence of projects may also have a feedback effect on the factors at household level, eg. through the provision of equipments and training. The right square box depicts the outcome from the adoption of MEs on poverty reduction. This may be observable through an increase in the monetary household income and in the proportion of the ME-income out of the total

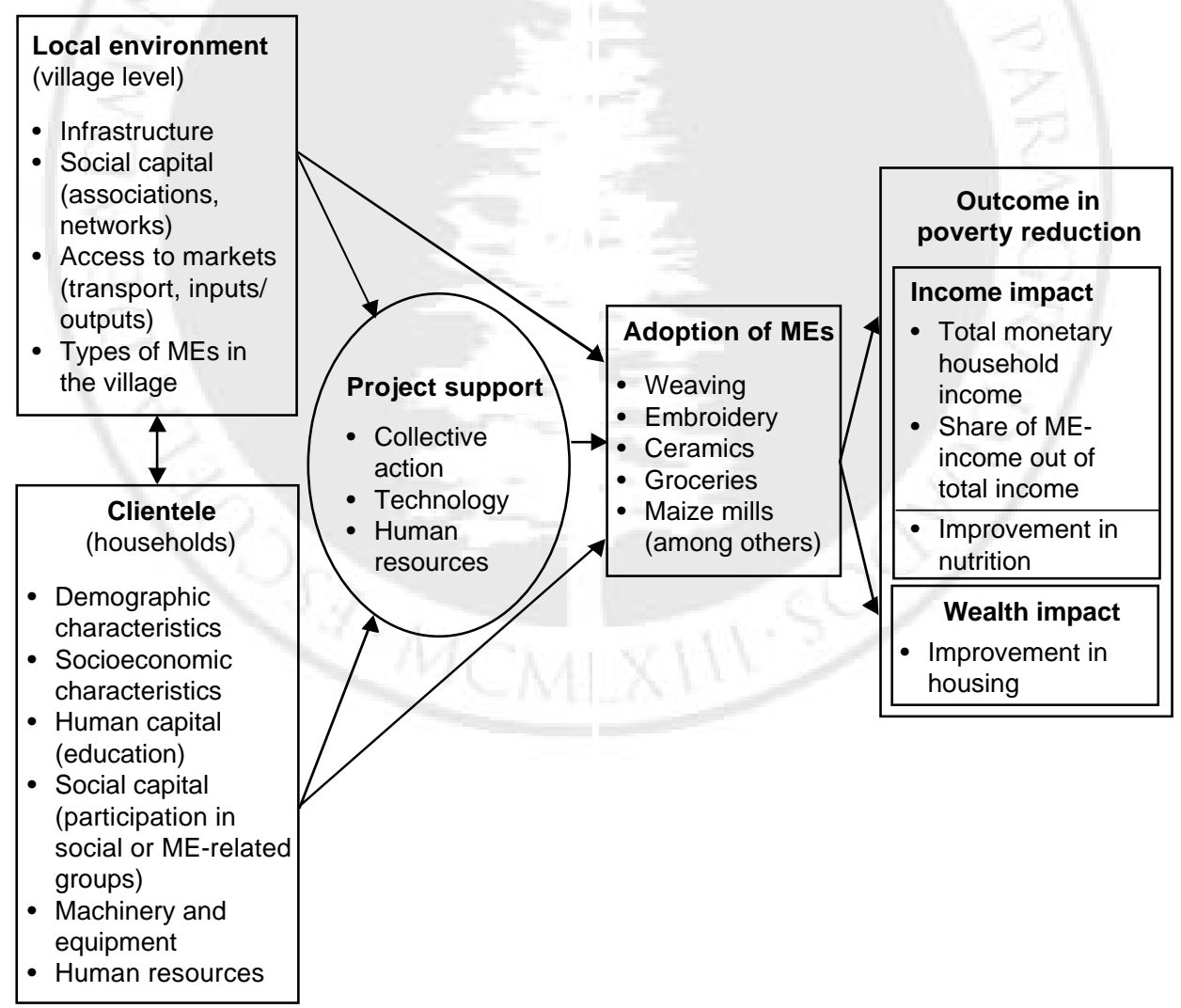

Source: Author.

Figure 1. The Conceptual Framework of the study 
household income. Also nutrition serves as an income indicator. The impact on wealth may be observable by an improvement in housing.

Based on the conceptual framework the study was designed to test the following hypotheses:

- It is hypothesized that social capital at both household and village level has a positive impact on the adoption of MEs.

- Membership in groups for collective action is hypothesized to enhance the outcome of ME-adoption and to favor the possibilities of higher-priced sales.

- The adoption of MEs and the participation in PRODEQ is expected to have a positive impact on the reduction in poverty of rural households in terms of the monetary household income.

- The adoption of MEs and the participation in PRODEQ is expected to have a positive impact on the housing conditions and the nutritional situation of rural households.

\section{Research methods and survey design}

\subsection{Research methods applied for the data analysis}

For the data analysis quantitative and qualitative research methods were applied. Comparative analyses have been used throughout the study to obtain information on significant relationships between variables. If the data are nominal or ordinal scaled the Pearson Chi-Square test was applied. Interval scaled data allowed to apply the independent t-test to compare two and the ANOVA-analysis to compare more than two population means.

Regression analyses have been included to measure casual relationships and to identify the significant impact of the explanatory variables on the dependent variables. To identify the determinants of dichotomous dependent variables the Probit model was applied, for regressing explanatory variables on continuous dependent variables the Ordinary Least Squares (OLS) regression was used.

The two stages least squares Heckman model has been applied to address the problem of selection bias in the case of self selection into sub-samples. Qualitative methods were applied for the case study of a weaving and ceramic group focusing on collective action supported by PRODEQ. The case study was carried out through the participation by the researcher in group meetings and in-depth interviews.

\subsubsection{Definition of the variables used in the study}

In the following the dependent and explanatory variables applied in the econometric analysis are defined, subsequently the functions and regression equations for each regression.

\subsubsection{Definition of the functions used for the econometric analyses}

The functions used in the regression analyses applied throughout the study are defined in Table 3. 
Table 1: Definition of the selected dependent variables

\begin{tabular}{|c|c|}
\hline $\begin{array}{l}\text { Name of dependent } \\
\text { variable }\end{array}$ & Definition \\
\hline$Y_{\text {adoptme }}$ & Dummy, if decided to adopt a ME-activity $(0=$ no, $1=$ yes $)$ \\
\hline$Y_{\text {propme }}$ & $\begin{array}{l}\text { Importance of ME-adoption, measured by the proportion of ME-income } \\
\text { out of totalhousehold income }\end{array}$ \\
\hline$Y_{\text {tothhinc }}$ & Total monetary annual household income (US \$) \\
\hline$Y_{\text {houseimp }}$ & Dummy, if housing improved compared to 3 years ago $(0=$ No, $1=$ Yes $)$ \\
\hline$Y_{\text {nutimp }}$ & Dummy, if nutrition improved compared to 3 years ago $(0=$ No, $1=$ Yes $)$ \\
\hline
\end{tabular}

Source: Author.

Table 2: Definition of the selected explanatory variables

\begin{tabular}{|c|c|c|}
\hline $\begin{array}{l}\text { Group of } \\
\text { explanatory } \\
\text { variables }\end{array}$ & $\begin{array}{l}\text { Name of } \\
\text { explanatory } \\
\text { variable }\end{array}$ & Definition \\
\hline $\begin{array}{l}\text { DEMOGRAPHIC } \\
\text { CHARACTERISTICS } \\
(=\mathrm{D})\end{array}$ & $\begin{array}{l}\text { HHSIZE } \\
\text { AGEHEAD } \\
\text { AGESQU } \\
\text { CLIFEM }\end{array}$ & $\begin{array}{l}\text { Number of members living in the household } \\
\text { Age of head of household (years) } \\
\text { Squared age of head of household (squared years) } \\
\text { Dummy, if client is female }(0=\text { No, } 1=\text { Yes) }\end{array}$ \\
\hline $\begin{array}{l}\text { EDUCAT } \\
\text { LEVEL }(=\end{array}$ & EDUCMAX & $\begin{array}{l}\text { Maximal education level in the household }(1=\text { secondary } \\
\text { school and technical career ended; } 2=\text { secondary school } \\
\text { completed; } 3=\text { primary school and technical career com- } \\
\text { pleted; } 4=\text { primary school completed; } 5=\text { at least three } \\
\text { years primary school attended; } 6=\text { One or two years pri- } \\
\text { mary school attended; } 7=\text { No school education) }\end{array}$ \\
\hline $\begin{array}{l}\text { SOCIAL } \\
(=\mathrm{S})\end{array}$ & $\begin{array}{l}\text { GROUPTOT } \\
\text { INSTKNOW } \\
\text { TIMEGROU }\end{array}$ & $\begin{array}{l}\text { Monetary help received by relatives or friends compared to } \\
\text { three years ago ( } 1 \text { = improved considerably; } 2 \text { improved } \\
\text { slightly; } 3 \text { situation maintained; } 4 \text { worsened slightly; } 5 \text { wor- } \\
\text { sened considerably) } \\
\text { Number of social or ME-related groups or committees where } \\
\text { the head of household or the spouse participates } \\
\text { Number of institutions known that provide ME-support } \\
\text { Time spent by head of household or spouse in each social } \\
\text { or ME-related group or committee (hours per month) }\end{array}$ \\
\hline $\begin{array}{l}\text { INCOME } \\
\text { CHARACTERISTICS } \\
(=I)\end{array}$ & $\begin{array}{l}\text { GESINNME } \\
\text { INCCAPIT } \\
\text { TOTHHINC } \\
\text { GMMEYEAR }\end{array}$ & $\begin{array}{l}\text { Annual household income not related to ME-activities (US \$) } \\
\text { Annual household income not related to ME-activities per } \\
\text { household member (US \$) } \\
\text { Total monetary annual household income (US \$) } \\
\text { Annual gross margin by ME-activity (US } \$ \text { ) }\end{array}$ \\
\hline $\begin{array}{l}\text { FARM } \\
\text { CHARACTERISTICS } \\
(=\text { F) }\end{array}$ & $\begin{array}{l}\text { FARMSIZE } \\
\text { MAIZEFER }\end{array}$ & $\begin{array}{l}\text { Total size of cultivated land (strings) } \\
\text { Dummy, if household purchased fertilizers for last growing } \\
\text { maize season }(0=\text { No, } 1=\text { Yes })\end{array}$ \\
\hline $\begin{array}{l}\text { MARKET ACCESS } \\
(=\mathrm{M})\end{array}$ & $\begin{array}{l}\text { TIMEDIST } \\
\text { MINROAD }\end{array}$ & $\begin{array}{l}\text { Minutes needed to get from the house to next district town } \\
\text { Walking distance from the house to next sand or gravel road } \\
\text { (minutes) }\end{array}$ \\
\hline ADOPTION $(=\mathrm{A})$ & ADOPTME & Dummy, if adoption of a ME-activity $(0=\mathrm{No}, 1=\mathrm{Yes})$ \\
\hline PART & & 1 =Yes) \\
\hline
\end{tabular}

Source: Author. 
Table 3

Functions of the dependent variables used in the study

\begin{tabular}{|lll|}
\hline Dependent variables & Function \\
\hline ME-adoption (decision to adopt a ME) & $Y_{\text {adoptme }}=f(D, E, S, I, F, M)$ \\
ME-adoption (Proportion of ME-income out & & \\
of total household income) & $Y_{\text {propme }}=f(D, E, S, I, F, M)$ \\
Total monetary household income & $Y_{\text {tothhinc }}=f(A, D, E, S, F, M)$ \\
Improvement in housing & $Y_{\text {houseimp }}=f(P, D, E, S, F, M)$ \\
Improvement in nutrition & $Y_{\text {nutimp }}=f(P, D, E, S, F)$ \\
\hline
\end{tabular}

Notes:

$\mathrm{D}=$ Demographic characteristics $\quad \mathrm{F}=$ Farm characteristics

$E=$ Education level $\quad M=$ Market access

$S=$ Social capital $\quad A=$ Adoption

$\mathrm{I}=$ Income characteristics $\quad \mathrm{P}=$ Participation

\subsubsection{Definition of the regression equations used in the study}

The following equations were used in the regression analyses applied throughout the study.

\section{Decision for ME-adoption}

The equation for the decision to adopt a ME-activity can be defined as:

$$
\begin{aligned}
\mathrm{Y}_{\text {ADOPTME } \mathrm{i}}=\beta_{0}+\beta_{1} * \operatorname{HHSIZE}_{\mathrm{i}}+\beta_{2} * \operatorname{AGEHEAD~}_{\mathrm{i}}+\beta_{3} * \text { AGESQU }_{\mathrm{i}} \beta_{4} * \text { EDUCMAX }_{\mathrm{i}}+ \\
{ }_{5} * \operatorname{HELPREC}_{1}+\beta_{6} * \text { GROUPTOT }_{\mathrm{i}}+\beta_{7} * \operatorname{INSTKNOW}_{\mathrm{i}}+\beta_{8} * \operatorname{GESINNME}_{\mathrm{i}}+ \\
\beta_{9} * \operatorname{INCCAPIT}_{\mathrm{i}}+\beta_{10} * \text { FARMSIZE }_{\mathrm{i}}+\beta_{11} * \operatorname{MAIZEFER~}_{\mathrm{i}}+\beta_{12} * \operatorname{TIMEDIST}_{\mathrm{i}}+\epsilon_{\mathrm{i}}
\end{aligned}
$$

Where in this and the following equations

$$
\begin{aligned}
\beta_{0} & =\text { constant term } \\
\beta_{1}, \ldots \beta_{12} & =\text { regression coefficients } \\
\epsilon & =\text { error term } \\
\mathrm{i} & =\text { household index }
\end{aligned}
$$

Importance of ME-adoption

For the importance of the adoption of a ME-activity measured by the proportion of the ME-income out of the total household income, the two-stages least square Heckman model is applied.

The equation for the first stage of the Heckman model can be defined as:

$$
\begin{aligned}
\mathrm{Y}_{\text {ADOPTMEi }}=\beta_{0}+\beta_{1} * \text { HHSIZE }_{\mathrm{i}}+\beta_{2} * \text { AGEHEAD }_{\mathrm{i}}+\beta_{3} * \text { AGESQU }_{\mathrm{i}}+\beta_{4} * \text { EDUCMAX }_{\mathrm{i}}+ \\
\beta_{5} * \operatorname{HELPREC}_{\mathrm{i}}+\beta_{6} * \text { GROUPTOT }_{\mathrm{i}}+\beta_{7} * \text { INSTKNOW }_{\mathrm{i}}+\beta_{8} * \text { GESINNME }_{\mathrm{i}}+ \\
\beta_{9} * \operatorname{INCCAPIT~}_{\mathrm{i}}+\beta_{10} * \text { FARMSIZE }_{\mathrm{i}}+\beta_{11} * \text { MAIZEFER }_{\mathrm{i}}+\beta_{12} * \text { TIMEDIST }_{\mathrm{i}}+\epsilon_{\mathrm{i}}
\end{aligned}
$$


The equation for the second stage of the Heckman model can be defined as:

$$
\begin{gathered}
\mathrm{Y}_{\text {PROPMEi }}=\beta_{0}+\beta_{1} * \text { EDUCMAX }_{\mathrm{i}}+\beta_{2} * \text { AGEHEAD }_{\mathrm{i}}+\beta_{3} * \text { AGESQU }_{\mathrm{i}} \beta_{4} * \text { HELPREC }_{\mathrm{i}}+ \\
\beta_{5} * \text { GROUPTOT }_{\mathrm{i}}+\beta_{6} * \operatorname{TIMEGROU~}_{\mathrm{i}}+\beta_{7} * \text { FARMSIZE }_{\mathrm{i}}+ \\
\beta_{8} * \operatorname{TIMEDIST}_{\mathrm{i}}+\beta_{9} * \operatorname{MINROAD}_{\mathrm{i}}+\beta_{10} * \operatorname{IMR}_{\mathrm{i}}+\epsilon_{\mathrm{i}} \\
\text { IMR = Investment Mills Ratio }
\end{gathered}
$$

\section{Total monetary household income}

The determinants which are expected to have an impact on the total household income considering ME-adoption are expressed by the following equation:

$$
\begin{aligned}
\mathrm{Y}_{\text {TOTнHINCi }}=\beta_{0}+\beta_{1} * & \text { ADOPT }_{\mathrm{i}}+\beta_{2} * \text { HHSIZE }_{\mathrm{i}}+\beta_{3} * \text { AGEHEAD }_{\mathrm{i}}+\beta_{4} * \text { EDUCMAX }_{\mathrm{i}}+ \\
& \beta_{5} * \text { GROUPTOT }_{\mathrm{i}}+\beta_{6} * \text { INSTKNOW }_{\mathrm{i}}+\beta_{7} * \operatorname{TIMEGROU~}_{\mathrm{i}}+\beta_{8} * \text { FARMSIZE }_{\mathrm{i}}+ \\
& \beta_{9} * \text { TIMEDIST }_{\mathrm{i}}+\epsilon_{\mathrm{i}}
\end{aligned}
$$

The determinants which are expected to have an impact on the total household income considering participation in PRODEQ are expressed by the following equation:

$$
\begin{aligned}
\mathrm{Y}_{\text {TOTHHINCi }}=\beta_{0}+\beta_{1} * & \text { MEMB }_{\mathrm{i}}+\beta_{2} * \text { HHSIZE }_{\mathrm{i}}+\beta_{3} * \text { AGEHEAD }_{\mathrm{i}}+\beta_{4} * \text { EDUCMAX }_{\mathrm{i}}+ \\
& \beta_{5} * \text { GROUPTOT }_{\mathrm{i}}+\beta_{6} * \text { INSTKNOW }_{\mathrm{i}}+\beta_{7} * \text { TIMEGROU }_{\mathrm{i}}+\beta_{8} * \text { FARMSIZE }_{\mathrm{i}}+ \\
& \beta_{9} * \text { TIMEDIST }_{\mathrm{i}}+\epsilon_{\mathrm{i}}
\end{aligned}
$$

\section{Improvement in housing}

The equation for an improvement in housing compared to three years ago can be defined as:

$$
\begin{aligned}
\mathrm{Y}_{\text {HOUSEIMPi }}=\beta_{0}+\beta_{1} * & \text { MEMB }_{\mathrm{i}}+\beta_{2} * \text { HHSIZE }_{\mathrm{i}}+\beta_{3} * \text { AGEHEAD }_{\mathrm{i}}+\beta_{4} * \text { EDUCMAX }_{\mathrm{i}}+\beta_{5} * \text { HELPREC }_{\mathrm{i}}+ \\
& \beta_{6} * \text { GROUPTOT }_{\mathrm{i}}+\beta_{7} * \text { INSTKNOW }_{\mathrm{i}}+\beta_{8} * \text { TIMEGROU }_{\mathrm{i}}+\beta_{9} * \text { FARMSIZE }_{\mathrm{i}}+ \\
& \beta_{10} * \text { TIMEDIST }_{\mathrm{i}}+\epsilon_{\mathrm{i}}
\end{aligned}
$$

\section{Improvement in nutrition}

The equation for an improvement in nutrition compared to three years ago can be defined as:

$$
\begin{aligned}
\mathrm{Y}_{\text {NUTIMPi }}=\beta_{0}+\beta_{1} * \operatorname{MEMB}_{\mathrm{i}}+\beta_{2} * \operatorname{HHSIZE}_{\mathrm{i}}+\beta_{3} * \text { EDUCMAX }_{\mathrm{i}}+\beta_{4} * \operatorname{HELPREC}_{\mathrm{i}}+\beta_{5} * \text { GROUPTOT }_{\mathrm{i}}+ \\
\beta_{6} * \operatorname{INSTKNOW}_{\mathrm{i}}+\beta_{7} * \operatorname{TIMEGROU}_{\mathrm{i}}+\beta_{8} * \operatorname{FARMSIZE~}_{\mathrm{i}}+\epsilon_{\mathrm{i}}
\end{aligned}
$$

\subsection{Survey design}

For the survey all five districts where PRODEQ operates were selected in order to obtain a total sample of 300 households.
In each of these districts, three villages were selected randomly among those were PRODEQ operates. For the selection of the households a stratified random sampling of equal representation of participat- 
ing households and non-participants in PRODEQ-activities has been drawn. Based on the data files provided by PRODEQ the participants among those having adopted an ME-activity were selected randomly. Lists obtained by the health service formed the basis to select randomly the non-participants. The survey was conducted in three rounds. During the first and second round of the survey all households were interviewed. For the third round all weaving and embroidery MEs (67 MEs) representing the handicraft sector were selected to identify specific issues related to social capital in the commercialisation process. The survey was complemented with a case study of a weaving and ceramic group focusing on collective action.

\section{Factors influencing the adoption of ME-activities}

The results of the study (see Table 4 and 5) reveal the existence of several determinants of the starting ME-activities considering two dimensions of adoption: First, the decision whether or not to adopt an ME-activity, secondly the importance of the decision to adopt for the income generated by ME-activities. The importance is represented by the proportion of the ME-income out of the total household income. Determinants identified with a significant impact are related to education, social capital, farm characteristics, and the access to markets.

The results reveal an important role of social capital in both dimensions of ME-

Table 4: Determinants on the decision to adopt a ME-activity, $\mathrm{Y}_{\text {adopt }}$ (Probit estimate) $^{2}$

\begin{tabular}{|lcrr|}
\hline Explanatory variable & Coefficient & t-value & \multicolumn{1}{c|}{ Mean } \\
\hline HHSIZE & 0,00838 & 0,170 & 6,070 \\
AGEHEAD & 0,00721 & 0,268 & 41,406 \\
AGESQU & $-0,00003$ & $-0,094$ & 1928,800 \\
EDUCMAX & 0,02847 & 0,366 & 6,320 \\
HELPREC & 0,10440 & 0,773 & 2,760 \\
GROUPTOT & 0,17300 & $3,575^{\star * *}$ & 3,603 \\
INSTKNOW & 0,08158 & 1,451 & 2,527 \\
GESINNME & 0,00002 & 0,602 & 997,590 \\
INCCAPIT & $-0,00001$ & $-0,085$ & 175,320 \\
FARMSIZE & $-0,00304$ & $-0,505$ & 14,600 \\
MAIZEFER & $-0,12787$ & $-0,411$ & 0,893 \\
TIMEDIST & $-0,00331$ & $-1,278$ & 75,680 \\
Constant & $-0,04678$ & $-0,46$ & \\
N $=300$ & & & \\
Chi-squared $=37,88^{* * *}$ & & & \\
Percentage predicted correctly $=75,33$ & & \\
\hline
\end{tabular}

Source: Own survey.

Notes: Dependent variable: YADOPTME Dummy, if decided to adopt an ME-activity $(0=$ no, $1=$ yes $)$. The explanatory variables have already been defined in Table 2.

*** Significant at the $1 \%$ level of error probability.

2. This Probit model also represents the first stage of the two stages least squares Heckman model on $\mathrm{Y}_{\text {propme }}$ applied in Table 5. 
Table 5

Determinants of the importance of ME-adoption

( $Y_{\text {propme, second stage of the Heckman model) }}$

\begin{tabular}{|lrrr|}
\hline Explanatory variable & Coefficient & t-value & Mean \\
\hline AGEHEAD & 0,00516 & 0,891 & 41,3463 \\
AGESQU & $-0,00005$ & $-0,794$ & 1914,9654 \\
EDUCMAX & 0,02760 & 1,605 & 6,2640 \\
HELPREC & 0,09309 & $3,042^{\star * *}$ & 2,7620 \\
GROUPTOT & $-0,00477$ & $-0,418$ & 4,0346 \\
TIMEGROU & 0,00807 & $2,792^{* * *}$ & 11,1732 \\
FARMSIZE & $-0,00029$ & $-1,631$ & 13,4420 \\
TIMEDIST & $-0,00217$ & $-3,450^{\star * *}$ & 74,6710 \\
MINROAD & $-0,00482$ & $-2,721^{* * *}$ & 11,3593 \\
IMR & 0,08221 & 0,516 & 0,3482 \\
Constant & 0,89660 & 4,399 & \\
N $=231$ & & & \\
$R^{2}$ (adjusted) $=0,178$ & & & \\
F $=5,98$ & & & \\
\hline
\end{tabular}

Source: Calculated on the basis of own survey.

Notes: Dependent variable: $\mathrm{Y}_{\text {PROPME }}=$ Importance of ME-adoption measured by the proportion of ME-income out of total household income.

The explanatory variables have already been defined in Table 2 .

IMR = Investment Mills Ratio.

*** Significant at the $1 \%$ level of error probability.

adoption. For the decision to adopt, the number of social or ME-related groups/ committees where the head of household or spouse participates has a highly significant impact. By contrast, for the proportion of the ME-income out of the total household income the time spent in each of these groups is relevant. This reflects on one hand the importance of socialization for the decision-making process. On the other hand, once having adopted MEactivities people spend more time in each group to enhance the entrepreneurial outcome. Furthermore, the implementation of activities such as collective action to put further an increase in the ME-income are time intensive.

\section{Groups of microentrepreneurs for collective action}

Since in the literature the issue of the formation of groups for collective action related to ME-activities has not yet been discussed in detail, the purpose is to analyze entrepreneurial groups pursuing collective commercialization and purchase of raw materials to enhance the outcome of their ME-activities.

\subsection{Support provided by PRODEQ in forming groups for collective action}

The support offered by the project focuses on the organizational structure of the 
group and the allocation of responsibilities among the group members, e.g. for the delivery of the products to the handicraft shop cooperative. The measures applied by PRODEQ for the formation of ME-groups consist of the implementation of shop cooperatives, training, technical assistance, and the provision of collective micro-credits. Specific issues related to ME-activities addressed in the training encompass entrepreneurial leadership, administration, and commercialization. However, to fulfill the integral approach, also aspects like nutrition, health, gender, and natural resources are raised in the training-schemes. The aim is to provide an understanding of the interdependency of these issues and to improve the sustainability of ME-activities.

\subsection{Case study of a weaving and ceramic ME-group supported by PRODEQ}

The attribution of responsibilities among the group members is an important precondition for an increase in profits and to reduce transaction costs. Through simultaneous training and technical assistance provided by PRODEQ the quality has been improved considerably. Furthermore, the greater extent of awareness on the products in the market makes possible to sell on a larger scale and to broaden the contacts to clients. Further diversification of products goes along with the demand structure of the newly acquired clients. The reinvestment of the generated resources represents the very factor of

Limitations before the implementation of the shop

- Low prices in sales

- High transaction costs

- Few people are aware of products

Reduction in transaction costs by allocation of responsibilities

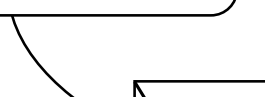

Reinvestment in ME-activities and assets to improve the standard of living

Orders on a large scale, expansion of market size

Source: Author.

Figure 2. Self-sustaining multiplier effect created by the handicraft shop 
making the multiplier effect self-sustaining. Reinvestment in the respective MEactivity makes possible a further increase in the business and to generate more income which is fundamental for poverty reduction. The multiplier effect created by the handicraft shop cooperative is illustrated in Figure 2.

\section{The impact of ME-activities and project support on poverty reduction}

\subsection{Total monetary household income}

The findings suggest that the factor with the strongest impact on the total monetary household income is the adoption of an ME-activity (see Table 6). Participation in
PRODEQ has also a positive impact though being less significant as compared to ME-adoption (see Table 7). Taking into account that MEMB and ADOPTME are collinear, only one of both variables can be included in one model. Thus, first the model is carried out considering ME-adoption, ${ }^{3}$ subsequently it is run replacing the variable «ADOPTME» by «MEMB».

At the $1 \%$ level of error probability the adoption of a ME-activity is significant proving its strong impact on poverty reduction. The participation in PRODEQ has also a positive impact on the monetary household income though being less significant as compared to ME-adoption. The highly significant differences in the income not related to ME-activities between par-

\section{Table 6}

Determinants of the total monetary annual household income considering ME-adoption: $\mathbf{Y}_{\text {tothhinc }}$ (OLS Estimate)

\begin{tabular}{|lrrr|}
\hline Explanatory variable & Coefficient & t-value & Mean \\
\hline ADOPTME & 8790,698 & $3,089^{* * *}$ & 0,770 \\
HHSIZE & 765,336 & 1,647 & 6,070 \\
AGEHEAD & 23,168 & 0,325 & 41,407 \\
EDUCMAX & 2252,806 & $2,508^{* *}$ & 6,320 \\
GROUPTOT & $-576,988$ & $-1,158$ & 3,600 \\
INSTKNOW & 580,729 & 0,934 & 2,530 \\
TIMEGROU & 417,689 & $2,599^{* * *}$ & 10,400 \\
FARMSIZE & 111,349 & 1,423 & 14,600 \\
TIMEDIST & $-81,867$ & $-2,726^{* * *}$ & 75,680 \\
Constant & 17196,193 & $2,041^{* *}$ & \\
N $=300$ & & & \\
$R^{2}($ adjusted $)=0,128$ & & & \\
F $=5,824^{* * *}$ & & & \\
\hline
\end{tabular}

Source: Calculated on the basis of own survey.

Notes: Dependent variable: $Y_{\text {тотнніпс }}=$ Total monetary annual household income.

The explanatory variables have already been defined in Table 2.

*** Significant at the $1 \%$ level of error probability.

** Significant at the $5 \%$ level of error probability.

3. According to Phi Cramer's the correlation coefficient between the adoption of a ME-activity and participation in PRODEQ is 0,531 , and the significance level is $0,000 * * *$, thus highly significant. 
Table 7:Determinants of the total monetary annual household income considering the participation in PRODEQ: $Y_{\text {tothhinc }}$ (OLS Estimate)

\begin{tabular}{|lccr|}
\hline Explanatory variable & Coefficient & t-value & Mean \\
\hline MEMB & 4804,602 & $1,834^{*}$ & 0,770 \\
HHSIZE & 783,175 & $1,664^{*}$ & 6,070 \\
AGEHEAD & 28,188 & 0,392 & 41,407 \\
EDUCMAX & 2279,027 & $2,508^{* *}$ & 6,320 \\
GROUPTOT & $-673,946$ & $-1,237$ & 3,600 \\
INSTKNOW & 604,057 & 0,953 & 2,530 \\
TIMEGROU & 417,400 & $2,563^{* *}$ & 10,400 \\
FARMSIZE & 115,034 & 1,448 & 14,600 \\
TIMEDIST & $-87,270$ & $-2,877^{\star * *}$ & 75,680 \\
Constant & 21636,450 & $2,581^{* * *}$ & \\
N $=300$. & & & \\
$R^{2}$ (adjusted) $=0,107$ & & & \\
F $=4,948^{* * *}$ & & & \\
\hline
\end{tabular}

Source: Calculated on the basis of own survey.

Notes:Dependent variable: $\mathrm{Y}_{\text {тотнніNс }}=$ Total monetary annual household income.

The explanatory variables have already been defined in Table 2.

*** Significant at the $1 \%$ level of error probability.

** Significant at the $5 \%$ level of error probability.

* Significant at the $10 \%$ level of error probability.

ticipants in PRODEQ and non-participants need to be highlighted. The annual income not related to $\mathrm{ME}$-activities achieved by the participants is nearly $50 \%$ above that yielded by the non-participants. A great variety of consultancy services provided by the project for many years plays a decisive role in the difference between the crop income generated by participants as compared to non-participants.

\section{Standard of living}

Poverty reduction is not only reflected by the monetary income but also through wealth indicators. Housing was chosen as one such wealth indicator. The dependent variable is related to the fact if the conditions of housing have improved in the last three years or not. The Probit model outlined in Table 8 suggests that participation in PRODEQ is the most significant determinant of housing conditions. At the 5\% level of error probability this factor is significant proving a strong impact on housing which represents a wealth indicator. Against the expectations, the results suggest that ME-adoption has no significant impact on housing and nutrition. If one would replace the explanatory variable MEMB by ADOPTME in the Probit models on $Y_{\text {houseimp }}$ and $Y_{\text {nutimp }}$ the effect of ME-adoption would be insignificant. Thus, ME-adopters achieving a total household income more than double compared to nonadopters tend not to reinvest in assets such as housing and nutrition to improve the standard of living. By contrast, participation in PRODEQ is the most significant determinant with a positive impact on an improvement in the conditions of housing compared to three years ago. This indicates that the households participating in PRODEQ reinvest their resources predominantly in housing which improves their standard of living. 


\section{Table 8}

Determinants of an improvement in housing compared to three years ago, Yhouseimp (Probit Estimate)

\begin{tabular}{|lccr|}
\hline Explanatory variable & Coefficient & t-value & Mean \\
\hline MEMB & 0,41366 & $2,191^{* *}$ & 0,510 \\
HHSIZE & $-0,02917$ & $-0,823$ & 6,050 \\
AGEHEAD & 0,00290 & 0,540 & 41,334 \\
EDUCMAX & 0,07269 & 1,093 & 6,290 \\
HELPREC & 0,01542 & 0,129 & 2,750 \\
GROUPTOT & $-0,04750$ & $-1,160$ & 3,720 \\
INSTKNOW & 0,07304 & 1,534 & 2,610 \\
TIMEGROU & 0,02110 & $1,787^{*}$ & 10,750 \\
FARMSIZE & 0,01667 & $2,113^{* *}$ & 14,560 \\
TIMEDIST & $-0,00049$ & $-0,221$ & 75,670 \\
Constant & 0,01901 & 0,700 & \\
N = 290 & & & \\
Chi-squared = 24,01 & & \\
Percentage predicted correctly $=64,48$ & & \\
\hline
\end{tabular}

Source: Calculated on the basis of own survey.

Notes: Dependent variable: $Y_{\text {Houselmp }}=$ Dummy, if housing improved compared to 3 years ago $(0=$ No, $1=$ Yes $)$.

The explanatory variables have already been defined in Table 2 .

*** Significant at the $1 \%$ level of error probability.

** Significant at the $5 \%$ level of error probability.

* Significant at the $10 \%$ level of error probability.

The project originally had its focus on nutrition and natural resources. Table 9 being related to the fact if the nutritional situation has improved during the last three years or not, shows that compared to three years ago the participants have improved their availability of nutrition to a greater extent than the non-participants. Moreover, a comparison of meals containing chicken and meat suggests similar consumption for both groups at present. Thus, the similar nutritional situation at present implies that three years ago the participants were in a worse nutritional conditions compared to the non-participants. This is an indication that PRODEQ has targeted the poor share of the population in the project area.

\section{Conclusions}

The conclusions drawn attempt to link the findings obtained in the field research with the hypotheses developed in the study. To provide a summarised illustration related to the conclusions drawn in the study, Table 10 confirms or rejects each hypothesis. The selected determinants representing social capital are not for all ME-branches and in both dimensions of ME-adoption (the decision to adopt and the importance of the decision for the income generated by ME-activities) significant. At both, household and village level, social capital, represented by the indicator «number of social or ME-related groups/committees where the head 
Table 9

Determinants of an improvement in nutrition compared to three years ago, $Y_{\text {nutimp }}$ (Probit Estimate)

\begin{tabular}{|lccc|}
\hline Explanatory variables & Coefficient & t-value & Mean \\
\hline MEMB & 0,36201 & $1,923^{*}$ & 0,51 \\
HHSIZE & 0,03967 & 1,106 & 6,05 \\
EDUCMAX & 0,04618 & 0,690 & 6,29 \\
HELPREC & 0,33009 & $2,664^{* * *}$ & 2,75 \\
GROUPTOT & $-0,02937$ & $-0,723$ & 3,72 \\
INSTKNOW & 0,16803 & $3,458^{* * *}$ & 2,61 \\
TIMEGROU & $-0,00590$ & $-0,517$ & 10,75 \\
FARMSIZE & 0,01680 & $2,131^{* *}$ & 14,56 \\
Constant & $-0,21482$ & $-0,361$ & \\
N $=290$ & & & \\
Chi-squared $=39,24^{* * *}$ & & & \\
Percentage predicted correctly $=65,00$ & & & \\
\hline
\end{tabular}

Source: Calculated on the basis of own survey.

Notes: Dependent variable: $Y_{\text {NUTIMP }}=$ Dummy, if nutrition improved compared to 3 years ago $(0=$ No, $1=$ Yes $)$

The explanatory variables have already been defined in Table 2

*** Significant at the $1 \%$ level of error probability

** Significant at the $5 \%$ level of error probability

* Significant at the $10 \%$ level of error probability

Table 10

Affirmation and rejection of hypotheses

\begin{tabular}{|ll|}
\hline \multicolumn{1}{|c|}{ HYPOTHESIS } & RESULT \\
\hline $\begin{array}{l}\text { Social capital has a positive impact on the adoption } \\
\text { of MEs }\end{array}$ & REJECTED \\
\hline $\begin{array}{l}\text { Membership in groups for collective action enhances } \\
\text { the outcome of ME-adoption and higher priced sales }\end{array}$ & AFFIRMED \\
\hline $\begin{array}{l}\text { ME-adoption and participation in PRODEQ has a } \\
\text { positive impact on the monetary huosehold income }\end{array}$ & AFFIRMED \\
\hline $\begin{array}{l}\text { ME-adoption and participation in PRODEQ has a } \\
\text { positive effect on housing and nutrition }\end{array}$ & REJECTED \\
\hline
\end{tabular}

Source: Author.

of household or spouse participates» is highly significant for the decision to adopt a ME-activity. These groups and committees exist in the villages (village level perspective) which is a frame condition for participation. The household members decide whether they participate or not (households perspective).
For the income proportion generated by ME-activities the time spent in social or ME-related groups or committees is significant rather than the number of groups where the head of household or spouse participate. Undoubtedly, more socialization in diverse groups or committees allows the interchange of business 
experiences resulting in an increasing likelihood to adopt a ME-activity. However, the implementation of activities to improve the ME-performance such as collective action requires to spend a certain minimum of time in each group. On the other hand, the decision to adopt a ME-activity serves as an incentive to dedicate more time for ME-related groups. Thus, after having set up a business, people spend more time in such groups in order to acquire further business skills and to enhance their ME-performance. Barr emphasizes that microenterprises tend to have intense contacts but to a small number of networks. MEs have a frequent interaction with each solidarity network they are in contact with but maintaining a relationship to only one third of the number of networks as compared to larger firms (Barr, 1998: 6).

According to the empirical results in the survey and the in-depth interviews it can be concluded that collective commercialisation based on a well organized allocation of responsibilities among the group members is favoring the ME-performance (measured by the ME-income) and the possibilities of higher priced sales. The support provided by PRODEQ is based on the rationale to provide assistance through a bundle of activities without neglecting any of them. One focus is collective action, providing simultaneously micro-credits, training and technical assistance to achieve a self-sustaining multiplier effect. Of particular importance is the handicraft shop cooperative implemented by PRODEQ to enhance the commercialisation of weaving and ceramic products. Collective action realizing the sales through the shop makes possible to reduce transaction costs and to increase profits. Based on a study on agriculture production cooperatives in Honduras, Ruerd emphasizes that economies of scale in marketing is restricted to collective production (Ruerd, 1999: 178). For this study it has been confirmed that through a clearly defined allocation of responsibilities among the group members such as the delivery of the products to the shop, essentially costs of transportations can be saved. Transaction costs can also be reduced through the purchase of raw materials carried out by one person on behalf of all group members.

Of particular interest is that in spite of achieving ME-adopters a total household income more than double compared to non-adopters, the results suggests that ME-adoption has no significant effect on housing and nutrition. By contrast, the influence of the participation in the project is remarkable with respect to an improvement in nutrition and wealth (represented by housing). The participation in PRODEQ is significant with respect to both, an improvement in nutrition and housing. One result related to the quality of nutrition deserves particular consideration. The differences in the means between participants and non-participants with respect to the consumed meals containing meat and chicken per month are minimal. This allows to derive the conclusion that the project targeted the poor. A regression analysis on nutrition suggests that compared to three years ago the participants have improved their availability of nutrition to a greater extent than the non-participants. Thus, the similar nutritional situation at present implies that three years ago the participants were in a worse nutritional situation as compared to the non-participants. This is an indication that PRODEQ has achieved the aim to target the poor share of the population in the project area. 
Taking into account the empirical results it can be concluded that the impact on poverty alleviation generated through the adoption of MEs and project activities is complementary. While ME-adoption leads to an increase in the monetary income level, one function of the project activities is to encourage reinvestment in assets to improve the quality of life. This process to create awareness among beneficiaries is an important part of the daily work in the project. The beneficiaries get gradually aware of the importance to reinvest available funds in assets to improve the quality of life and to expand their businesses. This is fundamental for the achievement of the self-sustaining multiplier-effect in poverty reduction. The question which has come up to what extent the beneficiaries are satisfied with their housing conditions would require further analysis taking into account the social and cultural background.

\section{References}

BARR, A. 1998. Enterprise performance and the functional diversity of social capital. Oxford: University of Oxford.

DE JANVRY, A. 1994.Farm-nonfarm synergies in Africa: Discussion. American Journal of Agricultural Economics. Ames Lowa Association.

FOOD AND AGRICULTURE ORGANIZATION (FAO). 1998. The state of food and agriculture. Rome: FAO.

GROOTAERT, C. 1998. Social capital, household welfare and poverty in Indonesia. The World Bank, Social Development Department, Environmentally and Socially Sustainable Development Network. Mimeo.

PETER, C. 1998. Plan de desarrollo forestal para el Municipio de San Andrés y Joya- baj. Santa Cruz del Quiché, Programa de Desarrollo Rural Regional en El Quiché (PRODEQ).

RUERD, R. 1999. Making cooperatives work, contact choice and resource management within land reform cooperatives in Honduras. Amsterdam: Centre for Latin American Research and Documentation (CEDLA).

UNITED STATES AGENCY FOR INTERNATIONAL DEVELOPMENT (USAID). 1997. Microenterprise business development services: Defining institutional options and indicators of performance. Washington D.C.

WORLD BANK.1996. Project report: Rural Poverty Alleviation Project. Washington D.C.: World Bank, Public Information Center. 